\title{
Vocabulary Teaching in Foreign Language via Audiovisual Method Technique of Listening and Following Writing Scripts
}

\author{
Ebubekir Bozavl1 ${ }^{1}$ \\ ${ }^{1}$ Education of Faculty, Atatürk University, Erzurum, Turkey \\ Correspondance: Ebubekir Bozavl, Education of Faculty, Atatürk University, Erzurum, Turkey. E-mail: \\ ebozavli@atauni.edu.tr
}

Received: February 18, 2017

Accepted: March 23, 2017

Online Published: April 29, 2017

doi:10.5539/ies.v10n5p129

URL: https://doi.org/10.5539/ies.v10n5p129

\begin{abstract}
The objective is hereby study is to compare the effects of conventional and audiovisual methods on learning efficiency and success of retention with regard to vocabulary teaching in foreign language. Research sample consists of 21 undergraduate and 7 graduate students studying at Department of French Language Teaching, Kazım Karabekir Faculty of Education, Ataturk University. The methodology applied herein is experimental research. Two groups of 14 were randomly established, one as experimental and one as control group. Experimental group underwent audiovisual method, while conventional vocabulary teaching method, still applied in schools, was applied on the control group. The data was gathered from instructive videos equipped with pedagogical references on the website of TV5 monde, under the title "Enseigner le français avec Tv 5 Monde" [Learn French with TV5 Monde]. Two practices, namely, "2001-2011: faut-il encore avoir peur du terrorisme" [2001-2011: Should we still fear terrorism?], "guerres et conflits: vers une privatisation générale?" [Wars \& conflicts: Towards an overall privatisation?], both at C1 education level, have been selected. Success rates in research data were found out by means of percentage calculations. The resulting values are analysed and interpreted through descriptive and content analysis methodology. According to research outputs, the learners are more successful in efficiency of learning and retention via audiovisual method than through conventional method. Simultaneous action of multiple sense organs and high motivation during learning process are considered as the principal reasons for such success.
\end{abstract}

Keywords: foreign language, vocabulary teaching, conventional method, audiovisual method, retention

\section{Introduction}

Word is the means of thought, expression, interpretation and communication. It enables individuals to think, speak and write in a reasonable manner (Tar, 2013). A child learns the vocabulary of his native language by means of interaction with his environment. The acquisition process begins with simple and concrete words such as "mama, papa" within the family; nevertheless, the process continues ceaselessly for long years as the child becomes more socialised and acquires complex and abstract words as well. Upon schooling, the volume of vocabulary, which is the most dynamic organism within language, increases in a systematic way; its acquisition during adulthood becomes an individual quality. Foreign language education, on the other hand, proceeds in unnatural environments; therein, vocabulary learning and teaching becomes complex. Learning in foreign language is much harder and more tiring than in mother tongue. Word is the most essential element of a foreign language (Galisson, 1983). Actually, instruction of grammar system of a language seems of top priority for communication; nevertheless, one inevitably has to have a wide vocabulary. Besides, words constitute the core for the verbal understanding and verbalising in a language (Coady, 1997). Difficulties in speaking a foreign language often arise from lack of knowledge with regard to grammar and vocabulary (Al Hosni, 2014). According to a study to determine requirements for development of English speaking skills at preparatory classes in Turkey (Deveci et al, 2016), students cannot speak English mostly because of overexcitement, fear of making mistakes and lack of sufficient vocabulary. Language learners need a wide array of target language words to be able to tackle successfully both production and comprehension activities in the second and foreign language (Ghazal, 2007). At this point, the importance of strategies for learning and teaching vocabulary becomes apparent. In general, vocabulary is taught in connection with other activities and pursuant to conventional approaches. Conventional learning strategies primarily focus on consultation to dictionary, noting down, 
repetition and analysis (Tar, 2013). Asgari (2011) lists the most common vocabulary learning strategies, including the rather contemporary ones, as follows "learning new words through reading, use of dictionaries, applying new words in daily speaking, using the English-language media (songs, movies, internet, computer games, TV programs etc.)". Among these approaches, the most important element to be questioned is keeping of the learned words in mind, namely, rate of retention. The focus should be on approaches that enable long-lasting transfer of new words to the memory. As for foreign language education in unnatural environments, in other words, in surroundings without any possibility of practice in social life, these units can be easily forgotten. A research on retention success of learners with regard to words in foreign language reveals that phonetic association is more effective than conventional methods (Bozavl1, 2017a). Oxford and Crookall (Op cit. Shen, 2003) make a classification of vocabulary teaching techniques from de-contextual to contextual: (a) de-contextualising: word lists, flashcards, dictionary use; (b) semi-contextualising: word grouping, visual imagery, association, keyword, aural imaginary, physical sensation, physical response, semantic mapping; (c) fully contextualising: reading, listening, speaking and writing. Today, learning proceeds upon a plane with integrity of topic. The most common method in foreign language education is to learn through lecture of a text that constitutes a context. The mind gives a meaning to written concepts and interprets them. In this regard, hereby study adds an audio aspect to the mentioned visual dimension. More precisely, the learner sees the concepts within a context in a text on the one hand, and hears their pronunciation on the other. The learner hears the pronunciations of concepts within a context, and does not read, but only follows them with his eyes. In this respect, hereby study tries to find out the effect of such audiovisual method on the success of vocabulary learning in foreign language. The study bears traces of SGAV (structuro-global audiovisual) method (Tagliante, 2006). SGAV, which concentrates on learning verbal language, is based on two essential principles. Structuro-global aspect believes in the necessity of provision of the learner with both linguistic (vocabulary \& grammar etc.) and non-linguistic (rhythm, stress, gestures and facial expressions) elements so as to ensure learning. The second principle, namely, the audio-visual aspect, seeks providing the learners with simultaneous presentation of voice and image in order to facilitate the comprehension of message. In the research, the first aspect is fulfilled by means of video pronunciations. As for the visuality, it is ensured by the words within the texts that are obtained through transformation of video pronunciations into writing. Visuality here means the form of words in written.

\section{Methodology}

The population of the survey consists of undergraduate and graduate students at Department of French Language Teaching, Kazım Karabekir Faculty of Education, Ataturk University. Total of 28 foreign language students have participated, with 21 undergraduates and 7 graduates. There are 18 female and 10 male participants in the population. The survey concentrates on undergraduate lecture on vocabulary.

Experimental research model is adopted as methodology (Giroux \& Tremblay, 2002). Two groups of 14 were randomly established, one as experimental and one as control group. The survey lasted with each group two weeks in different times. During the first week, the focus was on effectiveness of methods on vocabulary teaching, while we concentrated on the effect of methods on retention of vocabulary by learners in the second week. Experimental group was put to audio-visual method, while control group underwent the conventional vocabulary teaching method, currently applied at schools. Prior to the survey, a preliminary test was implemented on both groups so as to find out their level of knowledge on relevant words. During the first week, each group was subject to an application study of six hours in two sessions of 3 hours. Two days after the application study in week one, a word retention study was held for one hour. As for week two, the study took about one hour. There was no study on vocabulary learning during week two; following a short conversation, the students were provided a sheet to write down Turkish meanings of French words so as to find out how much they remember the words. Participants in experimental group were given the written text, decrypted from the context in the video, and they were asked to follow the pronunciation of the video on the written text during video stream on projection. In other words, they listened simultaneously to the pronunciations in the video and followed the writing scripts on the text. This first stage was repeated four times. Then, the text was analysed semantically by the participating researcher, 15 chosen words were written on the board together with their respective meaning, and they remained written on the board until the final minute of the survey. Students listened to these words again for several times, together with their pronunciations, the participants were asked to form sentences using these words and to share orally their phrases with the class. Besides, the video sections with these French words were listened afterwards and their respective meaning in Turkish was indicated. During the following days, the word retention study was organised for an hour; the words, written on the board, were repeated with their pronunciation and meaning. During the last five minutes of the course, words on the board were erased and the 
participants were given a form to write down meaning of the words. In week two, the participants were given the same form so as to measure how much they remember these words. As for control group, they were put to conventional word teaching method: They were given only the texts; first of all, the participating researcher read the entire text twice and then asked three voluntary participants to do the same. In the wake of reading process, the text was semantically analysed; the words, treated in the study, were written on the board and their respective meaning was explained. The passages with related words on the text were detected and the phrases that contain them were read for several times. In the following days, repetition courses were held for an hour each and the process continued with concentration on the mentioned words. In the end, the words were erased from the board and the forms were distributed to participants. As for week two, after a brief conversation, the participants were provided with the form so as to write down the meanings of respective words, just as in the experimental group.

Survey data was gathered from instructive videos equipped with pedagogical references on the website of TV5 Monde under the title "Enseigner le français avec TV5 monde" that seeks technological education of French as a foreign language by means of pedagogical methods and in an amusing way. Two applications at $\mathrm{C} 1$ instruction level called "2001-2011: faut-il encore avoir peur du terrorisme" and "guerres et conflits: vers une privatisation générale?" were chosen. The applications consist of an audiovisual video of about 15 minutes, in addition to an analysis chapter where the pronunciations of themes in the video are transformed into writing. Among two texts, each around 1200 words, which constituted the written format of video pronunciations, 30 French words, hitherto unknown and relatively more difficult, were selected so as to be asked to students to write down their Turkish meaning at the end of the practice. The words mostly consist of nouns and verbs. There are only 3 adjectives within. On Table 1, words in italic are derived from the material "guerres et conflits: vers une privatisation générale?", whereas the rest are obtained from "2001-2011: faut-il encore avoir peur du terrorisme”.

Table 1. Words derived from transformation of pronunciation of two videos into writing

\begin{tabular}{lll}
\hline La privatisation & Sanctionner & L'éxnophobe \\
L'opprobre & Perpetrer & L'audace \\
Le mercenaire & Résonner & L'envergure \\
Le révélateur & Traquer & Fracasser \\
L'arrogance & S'astreindre & Redouter \\
L'immunité & La juridiction & Pulvériser \\
La comparution & Le verdict & Prôner \\
L'externalisation & Contraignant & Exploser \\
L'égide & La prédication & Traitre \\
L'omniprésence & Le complice & Antagoniste \\
\hline
\end{tabular}

Survey data underwent percentage calculations in order to determine success rates. Emerging results were analysed and interpreted by means of descriptive and content analysis methodology (Y1ldırım \& Ali, 2000).

\section{Results}

The following survey data has been obtained.

Table 2. Test results-experimental group

\begin{tabular}{|c|c|c|c|c|c|c|c|c|}
\hline \multicolumn{5}{|c|}{ RESULTS - WEEK ONE } & \multicolumn{4}{|c|}{ RESULTS - WEEK TWO } \\
\hline 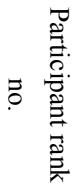 & $\begin{array}{c}\text { Correct } \\
\text { Words } \\
\text { Known } \\
\text { Beforehand }\end{array}$ & $\begin{array}{l}\text { Correct } \\
\text { Words }\end{array}$ & $\begin{array}{l}\text { Wrong } \\
\text { Words }\end{array}$ & $\begin{array}{c}\text { Success } \\
\text { Rate } \\
\%\end{array}$ & 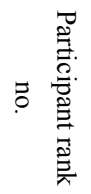 & $\begin{array}{l}\text { Correct } \\
\text { Words }\end{array}$ & $\begin{array}{l}\text { Wrong } \\
\text { Words }\end{array}$ & $\begin{array}{c}\text { Success Rate } \\
\%\end{array}$ \\
\hline 1 & - & 22 & 8 & 73.33 & 1 & 21 & 9 & 70 \\
\hline 2 & - & 18 & 12 & 60 & 2 & 20 & 10 & 66.66 \\
\hline 3 & - & 17 & 13 & 56.66 & 3 & 18 & 12 & 60 \\
\hline 4 & - & 21 & 9 & 70 & 4 & 21 & 9 & 70 \\
\hline 5 & - & 25 & 5 & 83.33 & 5 & 24 & 6 & 80 \\
\hline 6 & - & 19 & 11 & 63.33 & 6 & 18 & 12 & 60 \\
\hline 7 & - & 20 & 10 & 66.66 & 7 & 21 & 9 & 70 \\
\hline
\end{tabular}




\begin{tabular}{ccccccccc}
\hline 8 & - & 26 & 4 & 86.66 & 8 & 25 & 5 & 83.33 \\
9 & 1 & 19 & 11 & 63.33 & 9 & 20 & 10 & 66.66 \\
10 & - & 22 & 8 & 73.33 & 10 & 22 & 8 & 73.33 \\
11 & - & 20 & 10 & 66.66 & 11 & 20 & 10 & 66.66 \\
12 & - & 22 & 8 & 73.33 & 12 & 21 & 9 & 70 \\
13 & - & 24 & 6 & 80 & 13 & 22 & 8 & 73.33 \\
14 & - & 18 & 12 & 60 & 14 & 18 & 12 & 60 \\
\hline
\end{tabular}

At the time of preliminary test, only one participant knew the true meaning of French word "complice" in Turkish, among all others on Table 1 . Thanks to vocabulary teaching with audio-visual method, the experimental group attained a success rate between $56.66 \%$ and $86.66 \%$ in week one, while the retention percentage was between $60 \%$ and $83.33 \%$ in week two. At the end of the first week, 9 of 14 students were able to know the correct meaning of more than 20 of 30 words. The most successful participant gave 4 wrong answers. The numbers of correct answers by other five participants are 19 (2 participants), 18 (2 participants) and 17 (1 participant). No significant change was detected in the level of vocabulary knowledge of participants between the first and second week. At the end of week two, 6 participants gave fewer correct answers, while 4 enjoyed a rise and 4 remained unchanged. Rises and declines were restricted with one or two words. Therefore, the situation has no positive or negative effect on success. The rankings on Table 2 and 3 for the participants in both the experimental and control group are identical. In other words, a participant, which is in the top position in week one, retained his place in week two. Evidently, the ranking has to remain unchanged so as to observe the change in their respective success rate.

Table 3. Test results-control group

\begin{tabular}{|c|c|c|c|c|c|c|c|c|}
\hline \multicolumn{5}{|c|}{ RESULTS - WEEK ONE } & \multicolumn{4}{|c|}{ RESULTS - WEEK TWO } \\
\hline : & $\begin{array}{c}\text { Correct } \\
\text { Words } \\
\text { Known } \\
\text { Beforehand }\end{array}$ & $\begin{array}{l}\text { Correct } \\
\text { Words }\end{array}$ & $\begin{array}{l}\text { Wrong } \\
\text { Words }\end{array}$ & $\begin{array}{c}\text { Success Rate } \\
\%\end{array}$ & : & $\begin{array}{l}\text { Correct } \\
\text { Words }\end{array}$ & $\begin{array}{l}\text { Wrong } \\
\text { Words }\end{array}$ & $\begin{array}{c}\text { Success } \\
\text { Rate } \\
\%\end{array}$ \\
\hline 1 & - & 12 & 18 & 40 & 1 & 9 & 21 & 30 \\
\hline 2 & - & 10 & 20 & 33.33 & 2 & 8 & 22 & 26.66 \\
\hline 3 & - & 8 & 22 & 26.66 & 3 & 7 & 23 & 23.33 \\
\hline 4 & - & 11 & 19 & 36.66 & 4 & 9 & 21 & 30 \\
\hline 5 & - & 15 & 15 & 50 & 5 & 12 & 18 & 40 \\
\hline 6 & - & 9 & 21 & 30 & 6 & 7 & 23 & 23.33 \\
\hline 7 & - & 12 & 18 & 40 & 7 & 13 & 17 & 43.33 \\
\hline 8 & - & 11 & 19 & 36.66 & 8 & 9 & 21 & 30 \\
\hline 9 & - & 10 & 20 & 33.33 & 9 & 8 & 22 & 26.66 \\
\hline 10 & - & 12 & 18 & 40 & 10 & 10 & 20 & 33.33 \\
\hline 11 & - & 8 & 22 & 26.66 & 11 & 7 & 23 & 23.33 \\
\hline 12 & - & 9 & 21 & 30 & 12 & 5 & 25 & 16.66 \\
\hline 13 & - & 13 & 17 & 43.33 & 13 & 10 & 20 & 33.33 \\
\hline 14 & - & 14 & 16 & 46.66 & 14 & 9 & 21 & 30 \\
\hline
\end{tabular}

At the time of preliminary test, no control group member knew the Turkish meaning of any French word given on Table 1. By the end of week one, the most successful participant in control group attained a score of $50 \%$, while the least successful gave correct answers to $26.66 \%$ of the words. The objective at the end of week two was to detect the retention of Turkish meaning of French words taught during the first week. Success rates varied between $16.66 \%$ and $43.33 \%$. No group member could know more than 15 words. Only one participant gave correct answers for 15 words. 4 respondents gave less than 10 correct answers, while the rest scored between 10 and 14. By the end of week two, only one participant remembered the meaning of 13 words, while ten respondents could remember 5 to 10 words. 13 participants suffered a decline in retention success, while one enjoyed a rise, albeit limited to one word. 


\section{Discussion}

During week one on learning speed and week two on retention rate, the learners, who are provided with vocabulary teaching via audio-visual method, attained a success rate of around double of those subject to conventional methods. This fact may be associated, among other reasons, with their simultaneous use of multiple sense organs. Pursuant to relevant studies, a person can remember $10 \%$ of what he read, $20 \%$ of what he heard, $30 \%$ of he saw, $50 \%$ of what he saw and heard, $70 \%$ of what he said, and $90 \%$ of what he did and said (Koşar et al, 2004). In conventional method, the learners only heard the texts while the lecturer was reading; they read the text themselves when the lecturer stopped. Therefore, acts of reading and hearing occurred in different times. Besides, the voice they heard belonged to their lecturer, who was also an individual in their culture. As for audio-visual method, the learners both saw the written format of texts and listened to their pronunciation from a native speaker. Both acts occurred simultaneously in the mind of learners. This method recalls a fact that is actualised during the learning of native language. A baby, who acquires the mother tongue, listens to the spoken words around him before he begins to express himself. During the first years of his life, he hears millions of letters and syllables. In other words, he hears the vocals of the voice of the language even if he cannot express himself in early years; in the course of time, he constitutes the semantic structures of the language, grounding on the voices he heard. In a sense, linguistic development of a child proceeds from voice to meaning (Wauquier, 2006). As for hereby survey, the students, who were provided with audiovisual method, primarily heard the sounds of concepts in texts, before interpreting them in their mind.

As both vocabulary teaching methods were carried out with groups in separate times, the participants in experimental group were observed to display higher motivation skills anytime the process was put into practice. On the contrary, respondents in control group had a low level of motivation. In experimental group, the participants were more willing to learn, more active in learning with higher excitement of learning; the control group, however, displayed a low level of will and concentration, often exhibiting passive learning behaviours. Internal motivation factors were detected on the first group, while external factors were found out on the second. Motivation is one of the most influential factors on the learning process. Motivation becomes apparent in three ways namely, stimulation, orientation and result (Gil, 2014). Stimulation means triggering of learning act by a stimulus. Orientation signifies active participation of learner into the process; while the result means that the learner sees the result of his achievement and attains satisfaction. Motivation is a psychological and physiological process that starts, maintains and finalises behaviour. Such facts steer individuals to behave in this or that manner. For sure, it is much easier to teach something to motivated individuals than to unmotivated ones (Prochazkova, 2013).

As for retention rates at the end of week two, there is a high success rate in favour of audiovisual method. Retention rate is just above $70 \%$ with audiovisual method, while it is about $25 \%$ in conventional method. Possibilities of oral practice of language are limited in unnatural environments; accordingly, the retention of knowledge in mind is much more important than the speed of learning. One of the most challenging parts of every language learning is the acquisition of vocabulary items. Students, however, complain that they cannot remember the words they have learned (Amiryousefi \& Ketabi, 2011). When learning vocabulary, learners often have problems with retention of words for a long time. They usually fail to put the words into long-term memory. There are various reasons why students remember some words better than others: nature of the words themselves, situations under which the words are learnt, how they are taught to students and so on (Thuy, 2013). In this regard, effective methods, which will ensure that the word leaves a mark in the memory of students, should be preferred in vocabulary teaching. According to relevant studies, alternative vocabulary teaching methods ensure higher permanence of the knowledge than conventional ones. In his study on effects of keywords, context and word list strategies on long-term remembrance of the learned words, Tootkaboni (2012) concludes that the group, which learns the words through keyword technique, attains a higher level of success. Originally proposed by Atkinson, the keyword techniques is a mnemonic device used for helping learners to remember information easier. Keyword method divides vocabulary learning into two stages: an acoustic link stage and imagery link stage. In the first stage the learners are asked to associate the foreign word with the keyword, an association that is formed based on acoustic similarity. In the second stage the learners are asked to form a mental image of the keyword interacting with the English translation. Likewise, F. Kasper (1993) claims that the keyword is an effective method in remembering thanks to its quality of association. Every research (Baleghizadeh \& Ashoori, 2010; Hauptmann, 2004), in different regions with keywords of various contexts, yields results in favour of this method. Hauptmann chalks success of this method up to features such as "phonetic similarity, uniqueness, exaggeration, sensory nature, interactivity, creativity and simplicity". The relevant literature shows also significant effects of semantic concept maps on word memory. The study by Ngoc Thuy (2013) proves this 
finding. Thuy conducted an experimental study on high school students in order to analyse the effect of concept maps on their vocabulary memory, as well as the reactions of students to the method; the results indicated that the students in the experimental group outperformed those in the control condition in retaining word meanings and also proved that they had positive attitudes towards semantic mapping. This leads to the implication that the semantic mapping can improve high school students' vocabulary retention and is promising to vocabulary teaching and learning. Another research about effect of music on vocabulary teaching in foreign language and retention of words in the memory of learners reveals similar results. Pursuant to this study, those who learn with music remember more words than those who did not benefit from music; besides, the former are better motivated and listen to their teachers in a more attentive manner (Abdolmanafi-Rokni \& Ataee, 2014). Differently from the foregoing, another study (Bozavl1, 2017b) seeks revealing vocabulary teaching in foreign language by means of words with similar phonetics but different meaning within native languages; according to this research, phonetic association method has significant influence on permanence of learning. Similarities by means of phonetic association could be found between the words in Turkish, French and English. For example, "taş (pierre/stone) in Turkish and "tâche (task)" in French, and "sel/flood" in Turkish and "cell" in English, which are phonetically same but have different meanings, are different words. This study reveals that those learning English are better than those learning French in learning vocabulary by means of phonetic association and that both groups are generally more successful in recalling words.

\section{Conclusion and Suggestions}

There are two aspects of words in a natural language. The first is their pronunciation within speech, and the second is their graphic look (script) in the texts. Vocabulary education begins with pronunciation in native language and with graphic shapes in the foreign language. Conventional methods of vocabulary education for foreign language often disregard the phonetic aspect of the words. The individual either pronounces the words during the learning process in a text or even hears the pronunciation of the teacher. The student, therefore, does not hear their pronunciation in a sentence, and only hears the pronunciations of the words he has learned. However, language makes sense only upon aggregation of many concepts and grammatical elements. In hereby study, audiovisual method has been specifically applied on vocabulary teaching. In audiovisual method, spoken language is granted priority, before transition to the written (Güneş, 2011). However, this research has modified the mentioned characteristic of the method and opted for simultaneous utilisation of spoken and written language. Pronunciation of texts on video constitutes the oral aspect, while the scripts in writing contain the written aspect. Following the implementation of vocabulary teaching through conventional and audiovisual methods, it is concluded that the learners attain much better results with audiovisual methods in terms of learning and remembering effectiveness. The group, subject to audiovisual method, outperformed the second group with regard to speed of learning in week one and success of retention in week two. Success rates in first week are between $56 \%$ and $86 \%$, while retention rates in week two are between $60 \%$ and $83 \%$. As for the method who underwent conventional method, their success rates are between 26 and $50 \%$ for week one, and 16 and $43 \%$ for week two. Consequently, simultaneous stimulation of multiple sense organs and high motivation levels are considered to be influential in this success.

From this point forth, alternative methods should be employed in vocabulary teaching or learning in unnatural foreign language so as to ensure efficiency of retention. These methods can be implemented collectively in a class by means of a teacher, or even individually by the learner himself.

\section{References}

Abdolmanafi-Rokni, S., \& Ataee, A. J. (2014). The effect of background music on vocabulary recall and retention of children learning English as a foreign language. International Journal of Basic Sciences \& Applied Research, 3(8), 491-495.

Al Hosni, S. (2014). Speaking Difficulties Encountered by Young EFL Learners. International Journal on Studies in English Language and Literature, 2(6), 22-30.

Amiryousefi, M., \& Ketabi, S. (2011). Mnemonic Instruction: a way to boost vocabulary learning and recall. Journal of Language Teaching and Research, 2(1), 178-182. https://doi.org/10.4304/jltr.2.1.178-182

Asgari, A. (2011). The Type of Vocabulary Learning Strategies Used by ESL Students in University Putra Malasia. English Language Teaching, 4(2). https://doi.org/10.5539/elt.v4n2p84

Baleghizadeh, S., \& Ashoori, A. (2010). The Effect of Keyword and Word List Methods on Immediate Vocabulary Retention of EFL Learners. Pakistan Journal of Social Sciences (PJSS), 30(2), 251-261.

Bozavli, E. (2017a). Effect of Phonetic Association on Learning Vocabulary in Foreign Language. Journal of 
Education and Training Studies, 5(1). https://doi.org/10.11114/jets.v5i1.1968

Bozavli, E. (2017b). Effect of Phonetic Association on Lexis Learning in Natural Language Context: A comparative study of English, French and Turkish words. Educational Research and Reviews, 12(2), 45-53. https://doi.org/10.5897/ERR2016.3104

Coady, J. (1997). Research on ESL/EFL Vocabulary Acquisition: Putting it in Context. In T. Huckin, M. Haynes, \& J. Coady (Eds.), Second Language Reading and Vocabulary Learning (pp. 3-25). Norwood: Ablex.

Deveci, C. Ç., Buyruk, A. A., Erdoğan, P., \& Toy, B. Y. (2016). İngilizce Konuşma Becerisinin Öğretimine İlişkin İhtiyaçların Değerlendirilmesi. International Periodical for the Languages, Literature and History of Turkish or Turkic, 11/14, 915-934.

Galisson, R. (1983). D'hier à aujourd'hui, la didactique générale des langues étrangères. Paris: Cle International.

Ghazal, L. (2007). Learning Vocabulary in EFL Contexts through Vocabulary Learning Strategies. Novitas-Royal, 1(2), 84-91.

Gil, D. P. (2014). L'enseignement-apprentissage de vocabulaire en classe de FLE, proposition d'activités. Universidad de Valladolid, Facultad de Filosofia y Letras.

Giroux, S., \& Tremblay, G. (2002). Méthodologie des sciences humaines, la recherché en action. Québec: Erpi.

Güneş, F. (2011). Dil Öğretim Yaklaşımları ve Türkçe Öğretimindeki Uygulamalar. Mustafa Kemal University, Magazine of Institute of Social Sciences, 8(15), 123-148.

Hauptmann, J. (2004). The Effect of Integrated Keyword Method on Vocabulary Retention and Motivation. University of Leicester: School of Education.

Kasper, L. F. (1993). The keyword method and foreign language vocabulary learning: a rationale for its use. Foreign Language Annals, 26(2), 244-251. https://doi.org/10.1111/j.1944-9720.1993.tb01172.x

Koşar, E., Yüksel, S., Özkılıç, R., Avcı, U., İmer, G., \& Çiğdem, H. (2004). Öğretim Teknolojileri ve Materyal Geliştirme. Ankara: PegemA Yayıncılık.

Prochazkova, H. (2013). Enseigner le vocabulaire en classe de FLE. Plzen: Zapadoceska Univerzita.

Shen, W. W. (2003). Current Trends of Vocabulary Teaching and Learning Strategies for EFL Setting. Feng Chia University: Feng Chia Journal of Humanities and Social Sciences, 7, 187-224.

Tagliante, C. (2006). La classe de langue: Techniques et pratiques de classe. Paris: Clé Internationale.

Tar, M. (2013). L'acquisition du vocabulaire du français langue étrangère dans les universités nigérianes. Thèse de Doctorat. Nigeria: Département des langues Covenant University.

Thuy, N. N. (2013). The effects of semantic mapping on vocabulary memorizing. Retrieved August 11, 2013 from http:/www.fllt2013.org/privatefoler/Proceeding/628.pdf

Tootkaboni, A. A. (2012). Recall of foreign-language vocabulary: Effects of keyword, context and wordlist instructional strategies on long-term vocabulary recall of EFL learners. Journal of Theory and Practice in Education, 8(1), 54-71.

Wauquier, S. (2006). Du son au sens: acquérir ou apprendre la phonologie? Recherches linguistiques de Vincennes. En ligne: 2006, mis en ligne le 22 décembre 2006, consulté le 11 octobre 2012. Retrieved from http://rlv.revues.org/1411

Yıldırım, A., \& Şimşek, H. (2000). Sosyal Bilimlerde Nitel Araştırma Yöntemleri. Ankara: Seçkin Yayıncılık.

\section{Copyrights}

Copyright for this article is retained by the author(s), with first publication rights granted to the journal.

This is an open-access article distributed under the terms and conditions of the Creative Commons Attribution license (http://creativecommons.org/licenses/by/4.0/). 